\title{
Response Surface Methodology as a Tool for Optimization of Metal Adsorption by Banana Peel Biochar
}

\author{
P. Dhevagi*, S. Priyatharshini and A. Ramya \\ Department of Environmental Sciences, Tamil Nadu Agricultural University, \\ Coimbatore - 641003, India \\ Department of Agriculture, Irrigation and Livestock - Nangarhar Canal Project - Afghanistan \\ *Corresponding author
}

\section{A B S T R A C T}

\begin{abstract}
Agricultural wastes are considered as viable alternatives because of their abundant availability, low cost and also with various functional groups such as carboxylic acid, ester, carboxylate, hydroxyl, phenolic and amino that can act as adsorption sites for heavy metal ion. Banana peel waste based biosorbents to remove cadmium from waste water was taken up for the present study. Banana peel biochar was used as biosorbent and biosorption study was conducted at different $\mathrm{pH}(4,5,6,7$ and 8$)$, different concentration $(0,10,25$, $50,75$ and $100 \mathrm{ppm})$ and different contact time $(0,1,2,3,4,6$ and $8 \mathrm{~h})$. The adsorption of $\mathrm{Cd}$ by BPB was increased along with increase of $\mathrm{pH}$ from 4 to 7 , followed by $\mathrm{pH} 8$. The highest adsorption (91.51\%) was observed at $\mathrm{pH} 7$ and $75 \mathrm{ppm}$ concentration. The adsorption of $\mathrm{Cd}(86.69 \%)$ was recorded in 6 hours contact time. The FTIR spectrum of BPB after Cd adsorption revealed a large number of peaks within the interval of 4000-400 $\mathrm{cm}^{-1}$. Alkane functional group with $(\mathrm{C}-\mathrm{H})$ band was detected at $2918.73 \mathrm{~cm}^{-1}$ frequency before adsorption but after adsorption of $\mathrm{Cd}$, it was decreased to $2917.77 \mathrm{~cm}^{-1}$. Alkene functional group with $(=\mathrm{C}-\mathrm{H})$ band was reported at $997.982 \mathrm{~cm}^{-1}$ adsorption frequency before adsorption but after adsorption of $\mathrm{Cd}$, the alkene functional group was changed to ether with $(\mathrm{C}=\mathrm{O})$ band at $1013.41 \mathrm{~cm}^{-1}$ frequencies. There were no changes in Alkyl Halide functional group before adsorption and after adsorption of $\mathrm{Cd}$. Hence, the presence study with BPB for Cd removal is effective due to the negative surface charge on the of the biochar. It also an ecofriendly technique to remove heavy metal from the wastewater.
\end{abstract}

\section{Introduction}

Heavy Metal contamination is gradually more being recognized now a day in the developing world mainly in India and China (Cheng, 2003).Cadmium, the seventh most toxic metal as per according to ATSDR (2007), instigates cancer, damage to bones, kidney and mucus membrane. It also causes vomiting and affects hormone secretion. The search for new technologies to remove toxic metals from wastewaters has directed attention to biosorption, which is an economically affordable alternative, remains one of the key priorities among researchers. Only within the past decade the potential of metal biosorption by plant based materials have been recognized. Many crop residues are good 
adsorbents better than activated carbon and ion exchangers and remain unused. These waste materials contains various functional groups such as carboxylic acid, ester, carboxylate, hydroxyl, phenolic and amino that can act as adsorption sites for heavy metal ion (Ashraf et al., 2011).

Banana (Musa sapientum) is one of the most popular fruit crop grown in more than 130 countries, particularly in tropical and subtropical regions of the world. Banana peel, represents about $40 \%$ of total weight of the fresh fruit, totally 40 million tons of banana peel generated annually (Anhwange and Joseph, 2009), is considered to be a waste material. Exploring alternative uses of banana peel would thus bring an additional value to the industry. As reported by Mohapatra et al., 2010, banana peel is found to be a good source of pectin $(10-21 \%)$, lignin (6-12\%), cellulose (7.6-9.6\%), hemicelluloses (6.4-9.4\%), and galactouroninc acid.

Annadurai et al. (2002) reported that acid $\left(\mathrm{HNO}_{3}\right)$ and alkali $(\mathrm{NaOH})$ treated banana peels showed adsorption capacity of divalent heavy metal ions and the maximum metal adsorptions were recorded as $7.97\left(\mathrm{~Pb}^{2+}\right), 6.88$ $\left(\mathrm{Ni}^{2+}\right), 5.80\left(\mathrm{Zn}^{2+}\right), 4.75\left(\mathrm{Cu}^{2+}\right)$, and $2.55 \mathrm{mg}$ $\mathrm{g}^{-1}\left(\mathrm{Co}^{2+}\right)$. Practical applicability of banana peel to remove arsenic from contaminated water samples collected from 8 different areas of Sindh, Pakistan was reported by Jamil et al., (2008).

Anwar et al., (2010)studied the effect of adsorbent dosage 10-90 g/L on the adsorption of $\mathrm{Cd}^{2+}$ and $\mathrm{Pb}^{2+}$ and the maximum removal was observed at the doses of 30 and $40 \mathrm{~g} / \mathrm{L}$, respectively, for $\mathrm{Cd}^{2+}(89.2 \%)$ and $\mathrm{Pb}^{2+}(85.3 \%)$. Thorough scanning of literatures showed that only limited work has been carried out with reference to banana peel as adsorbent especially for cadmium. Hence an attempt to develop banana peel based adsorbent may provide a viable solution to removal of cadmium from wastewater.

\section{Materials and Methods}

\section{Collection and preparation of banana peel biochar}

The banana peels were collected from the nearby chips industry and the peels were thoroughly washed with tap water to remove external dust particles and kept in sunlight for drying. After sun drying, the banana peels were kept in an oven at $70^{\circ} \mathrm{C}$ for $2 \mathrm{~h}$ and used for biochar preparation. Banana Peel biochar (BPB) was prepared through the process of slow pyrolysis at $400-600^{\circ} \mathrm{C}$ at the Department of Bioenergy, Tamil Nadu Agricultural University, Coimbatore to obtain a stable product that was used as biochar.

The charcoal obtained in the reactor is calculated as,

Charcoal Yield, \%

$=\frac{\text { weight of charcoal }}{\text { weight of biomass }} * 100$

\section{Characterization of banana peel biochar}

The Banana Peel Biochar (BPB) was subjected to various characterization analyses such as electrochemical properties, biochemical components, elemental composition and Fourier Transform InfraRed Spectroscopy (FTIR). The electrochemical properties like $\mathrm{pH}, \mathrm{EC}$ and CEC ((Jackson, 1973), Organic carbon ((Jackson, 1973)), Total Nitrogen, Crude fiber and Protein content (Sadasivam and Manickam, 2009), Moisture content, Ash content (Gupta, 2007) of the BPB was analysed as per the standard methods. Pectin was extracted from sample through Gravimetric Method (Sadasivam and Manickam, 2009). 
Elemental composition in BPB was determined as per standard methods. Total Nitrogen was determined as per MicroKjeldahl Method and Total Phosphorus and Total Potassium was estimated in Flame photometer (Jackson, 1973). Calcium and Magnesium was estimated by Versenate titration (EDTA) and Sodium was determined by Flame photometer method (Gupta, 2007).

Iron, Manganese and Zinc was determined in atomic absorption spectrophotometer method (Tandon, 2013). The elemental composition of specimen surfaces and the percentage weight of chemical compositions were analysed in EDX analyser (Jamil et al., 2008).

Before and after adsorption of $\mathrm{Cd}$ the banana peel biochar was analyzed for the presence of functional groups by FT-IR(Model 8400S of Shimadzu, Japan) using Attenuated Total Reflectance (ATR) technique having wavelength source of $\left(400-4000 \mathrm{~cm}^{-1}\right)$ (Trakal et al., 2014). The surface charge of BPB samples were determined by measuring the zeta potential (Ucar et al., 2014).

\section{Optimization of adsorption potential of BPB}

A batch study was carried out to optimize the various incubation conditions for metal adsorption. Adsorption of Cadmium was studied at different incubation time, different metal concentration and various $\mathrm{pH}$. The dose of adsorbents was $1 \mathrm{~g}$ in $100 \mathrm{ml}$ working standard solution, size was $0.5 \mathrm{~mm}$ and equilibration time was $24 \mathrm{~h}$ at room temperature. The various $\mathrm{pH}$ employed here are 4 to 8 , contact time from 0 to $8 \mathrm{hrs}$ and concentrations were $25,50,75$ and $100 \mathrm{mgL}^{-1}$. $\mathrm{CdCl}_{2} . \mathrm{H}_{2} \mathrm{O}$ was used to prepare different concentrations of $\mathrm{Cd}$. All the treatments were replicated thrice with and without banana peelbiochar.

\section{AAS analysis}

The samples were analyzed spectrophotometerically using Atomic Absorption Spectrophotometer (Perkin Elmer) in the Department of Environmental Science, TNAU by using appropriate instrumental parameters. The amount of heavy metal adsorbed per unit mass of the adsorbent (Q) was calculated by using the following equation (Priyanka, 2017):

Adsorption $\%=\frac{(\mathrm{Ci}-\mathrm{Cf})}{\mathrm{Ci}} \times 100$

Where, $\mathrm{C}_{\mathrm{i}}$ is the initial concentration of metal ion in solution before sorption $\left(\mathrm{mg} \mathrm{L}^{-1}\right), \mathrm{C}_{\mathrm{f}}$ is the final metal ion concentration after the sorption analysis $\left(\mathrm{mg} \mathrm{L}^{-1}\right)$.

\section{Response Surface Methodology (RSM)}

Optimization of various conditions for the biosorption of cadmium $(\mathrm{Cd})$ was determined by response surface methodology (RSM). Central composite design (CCD) was used to study the effects of three independent variables viz., initial metal concentration, contact time and initial $\mathrm{pH}$ on the $\mathrm{Cd}$ removal(\%)(Ghosh et al., 2015).The central composite design was used due to its suitability to fit quadratic surface which usually works well for process optimization.

For statistical calculation, the variables were coded as given below:

$$
x_{i}=\frac{x_{i}-x_{0}}{\Delta \mathrm{x}}(1)
$$

Where $X_{i}$ is the dimensionless coded value of the $I$ th independent variable, $X_{0}$ is the value of $X_{i}$ at the centre point and $\Delta X$ is the step change value. The behaviour of system is explained by the following empirical second-order polynomial model 


\section{$Y=\mathrm{b} 0+\mathrm{b} 1 \mathrm{~A}+\mathrm{b} 2 \mathrm{~B}+\mathrm{b} 3 \mathrm{C}+\mathrm{b} 12 \mathrm{AB}+\mathrm{b} 13 \mathrm{AC}+\cdots$ Adsorption efficiency at varied pH and} concentration

Where $Y$ is the predicted response, bn is the coefficient associated with factor $\mathrm{n}$, and the letters, A, B, C,... represent the variables in the model.

The DESIGN EXPERT 6.07 (Stat-Ease Inc., Minneapolis, cMN, USA) software was used for regression and graphical analysis of the data. By solving regression equation of the desired variables, the optimum values of the selected variables were obtained as the optimization criteria. The variable A (Initial metal concentration) varied from 25 to 100 , $\mathrm{B}$ (Contact time) varied from 0 to 8 and variable $\mathrm{C}(\mathrm{pH})$ varied between 4 to 8 .

\section{Results and Discussion}

\section{Characterization of Banana Peel Biochar (BPB)}

The biochar was prepared from the dried banana peel by slow pyrolysis process and the final product obtained was used as banana peel biochar. Banana Peel Biochar (BPB) had alkaline $\mathrm{pH}$ (9.96) with an EC of $2.95 \mathrm{dS} \mathrm{m}^{-1}$. The alkaline $\mathrm{pH}$ of biochar may be effected by the release of alkali salts from feedstock during pyrolysis (Ahmad et al., 2012). The $\mathrm{CEC}$ of BPB was higher and the reason for high CEC in biochar might be due to increase in surface area after pyrolysis and also increase in charge density on the surface (Gomez-Eyles et al., 2013, Natalia et al., 2017). The zeta potential measurement indicated that BPB are negatively charged which indicates stability of the particles in banana peel (Kokila et al., 2015).

The Banana Peel Biochar showed a carbon content of $20.32 \%$ and this may be due to evaporation of some amount of carbon as $\mathrm{CO}_{2}$ or CO during pyrolysis.
The adsorption behavior of biochar for different contaminants (i.e., heavy metals, organic pollutants and other pollutants) are different and well correlated with the properties of contaminants. In addition, the adsorption mechanism may also depend on various properties like surface functional groups, specific surface area, porous structure and mineral components.

As for as heavy metals are concerned the possible adsorption mechanisms usually involves integrative effects of several kinds of interactions including electrostatic attraction, ion-exchange, physical adsorption, surface complexation and/or precipitation. The appropriate sorption of banana peel biochar makes a great contribution to the adsorption of heavy metals. Therefore, the adsorption efficiency of BPB at different $\mathrm{pH}$, varied $\mathrm{Cd}$ concentrations and different equilibration time were studied as batch experiment.

In the present experiment the adsorption of $\mathrm{Cd}$ by BPB was studied at different metal concentrations $(25,50,75,100 \mathrm{ppm}$ along with control) and varied $\mathrm{pH}$. The cadmium removal percentage was highest at $75 \mathrm{ppm}$ $(77.85 \%)$ and the lowest was detected at 25 ppm $(57.19 \%)$.

The removal of $\mathrm{Cd}$ was increased along with increase of $\mathrm{pH}$ from 4 to 7 . The maximum $\mathrm{Cd}$ removal $(80.56 \%)$ was observed at $\mathrm{pH} 7$, followed by $75.53 \%$ at $\mathrm{pH} 8$ and the lowest adsorption was recorded at $\mathrm{pH} 4(55.76 \%)$.

Interaction effect of different concentrations and $\mathrm{pH}$ was found to be significant on removal percentage of $\mathrm{Cd}$ by $\mathrm{BPB}$. The $\mathrm{pH}$ is one of the main variable affect the adsorption process, influencing not only the speciation of the metal ions, but also the surface charge of 
the metal ions, surface charge of the sorbent and the degree of ionization of the adsorbent during the reaction (Kilic et al., 2013).

In case of BPB, there was an increase in the adsorption of $\mathrm{Cd}$ (Fig. 1) at $\mathrm{pH} 7.0$ and minimum adsorption was at $\mathrm{pH}$ 4.0. Similar observations of higher adsorption at higher $\mathrm{pH}$ $>6$ were reported by Kilic et al., (2013) and Ucar et al., (2014).

Liu and Zhang (2010) that reported at lower $\mathrm{pH}$, the surface functional groups (mainly oxygen containing groups) bind to the $\mathrm{H}^{+}$, making these inaccessible for $\mathrm{Pb}$ ions. With increasing $\mathrm{pH}$, the deprotonating functional groups provided the chance to co-ordinate with $\mathrm{Cd}$ and $\mathrm{Pb}$ ions resulting in higher removal percent.

The removal efficiency of $\mathrm{Cd}$ by BPB was also increased with the increasing in the concentration from 25 to $75 \mathrm{ppm}$, and then decreased with the increasing of concentration.

The maximum adsorption of $\mathrm{Cd}(91.51 \%)$ was observed in $75 \mathrm{ppm}$ and the minimum was at 25 ppm solution. The capacity of banana peel increases with increasing concentration of metal ions. But if the substrate dose remains constant the removal efficiency may be reduced even if the metal concentration increases (Zhou et al., 2007).

At higher dose, overcrowding of adsorbent particle leads to overlapping and aggregation at adsorption sites reduces the adsorption capacity. BPB showed more efficiency, which may be due to creation of large internal surface area in a limited volume leads to small sized pores which might be the reason for more adsorption by biochar. The existence a macrospores also might have facilitated the adsorption.
Effects of metal ions concentration and contact time

The adsorption of $\mathrm{Cd}(\mathrm{II})$ by $\mathrm{BPB}$ was analyzed based on contact time. It ranged from 0-8 hours under shaking at $250 \mathrm{rpm}$ of $\mathrm{Cd}$ solution. The control ( 0 ppm or without metal) solution was not detectable at different time interval. Removal percentage of $\mathrm{Cd}$ by BPB increased with the increase in contact time from 0-6 $\mathrm{h}$, after then decreased with increase of time. The highest removal percentage of $\mathrm{Cd}$ $(75.20 \%)$ was recorded at $6 \mathrm{~h}$. The lowest adsorption $(26.31 \%)$ of $\mathrm{Cd}$ was noted at $0 \mathrm{~h}$ equilibration period. Interaction effect of time and $\mathrm{Cd}$ ions concentration was also found to be significant. The highest removal of $\mathrm{Cd}(86.69 \%)$ was observed at $6 \mathrm{~h}$ and $75 \mathrm{ppm}$.

Present study is well correlated with the observation of Anwar et al., (2010) who determined that adsorption of $\mathrm{Cd}$ by banana peel increases with increase in contact time and agitation speed ( Priyanka, 2017). The adsorption of metal ions gradually decreases as time progressed. This might be due to ions have to pass through the deeper surface of the pores, which encounter substantial resistance leading to decreased adsorption during the later phase of the study (Srivastava et al., 2016). And also the transportation rate of ions from the exterior to the interior sites of the adsorbent particles actually determines the adsorption rate of later phase (Shafaghat et al., 2012).

\section{Fitting the model}

The results obtained with the experimental design that was focused at identifying the best levels of the selected variables, contact time $(0-8), \mathrm{pH}$ (4-8) and initial metal ion concentration (25-100 ppm). The second order polynomial equation was used to find out the relationship between variables and response (Table 1 and 2). 
Table.1 Electrochemical and biochemical characteristics of BPB

\begin{tabular}{|c|c|c|}
\hline S.No. & Parameter & BPB* \\
\hline 1 & $\mathrm{pH}$ & 9.96 \\
\hline 2 & EC $\left(\mathrm{dSm}^{-1}\right)$ & 2.95 \\
\hline 3 & CEC $\left(\mathrm{c} . \mathrm{mol}\left(\mathrm{P}^{+}\right) \mathrm{kg}^{-1}\right)$ & 10.4 \\
\hline 4 & Particle size $(\mathrm{nm})$ & 11315.6 \\
\hline 5 & Zeta potential $(\mathrm{mV})$ & -20.0 \\
\hline 6 & Organic Carbon $(\%)$ & 20.32 \\
\hline 7 & Crude protein (\%) & 15.31 \\
\hline 8 & Crude Fiber $(\%)$ & - \\
\hline 9 & Protein (\%) & - \\
\hline 10 & Carbohydrate (\%) & - \\
\hline 11 & Cellulose (\%) & - \\
\hline 12 & Hemicellulose $(\%)$ & - \\
\hline 13 & Pectin (\%) & - \\
\hline 14 & Moisture content $(\%)$ & 7.5 \\
\hline 15 & Dry Matter $(\%)$ & 92.5 \\
\hline 16 & Ash content (\%) & 17 \\
\hline
\end{tabular}

Table.2 Mineral composition of BPB

\begin{tabular}{|c|c|c|}
\hline $\begin{array}{c}\text { S. } \\
\text { No. }\end{array}$ & Element & $\begin{array}{c}\text { BPB } \\
\left(\mathbf{m g ~ g}^{-\mathbf{1}}\right)^{*}\end{array}$ \\
\hline $\mathbf{1}$ & Total Nitrogen & 15.2 \\
\hline $\mathbf{2}$ & Phosphorus & 5.51 \\
\hline $\mathbf{3}$ & Potassium & 36.42 \\
\hline $\mathbf{4}$ & Calcium & 12.43 \\
\hline $\mathbf{5}$ & Magnesium & 10.87 \\
\hline $\mathbf{6}$ & Sodium & 25.65 \\
\hline $\mathbf{7}$ & Iron & 0.18 \\
\hline $\mathbf{8}$ & Manganese & 42.14 \\
\hline $\mathbf{9}$ & Zinc & 0.13 \\
\hline
\end{tabular}

*Value represents means of three replications. 
Table.3 ANOVA for quadratic model of banana peel biochar

\begin{tabular}{|c|c|c|c|}
\hline Source & Sum of Squares & df & $\begin{array}{c}\text { p-value }(<\mathbf{0 . 0 0 0 1} \\
\text { significant })\end{array}$ \\
\hline Model & 5680.69 & 5 & $<0.0001$ \\
\hline A-Concentration & 1095.54 & 1 & $<0.0001$ \\
\hline B-Time & 3229.91 & 1 & $<0.0001$ \\
\hline AB & 0.6191 & 1 & 0.7457 \\
\hline $\mathbf{A}^{2}$ & 210.33 & 1 & 0.0001 \\
\hline $\mathbf{B}^{2}$ & 1276.37 & 1 & $<0.0001$ \\
\hline Residual & 55.70 & 10 & \\
\hline Lack of Fit & 55.70 & 5 & \\
\hline Pure Error & 0.0000 & 5 & \\
\hline Cor Total & 5736.40 & 15 & \\
\hline
\end{tabular}

Table.4 Fit statistics

\begin{tabular}{|c|c|c|c|}
\hline \multicolumn{2}{|c|}{ Banana peel biochar } & \multicolumn{2}{c|}{ Banana peel biochar } \\
\hline Std. Dev. & 2.36 & $\mathrm{R}^{\mathbf{2}}$ & 0.9903 \\
\hline Mean & 59.86 & Adjusted R & 0.9854 \\
\hline C.V. \% & 3.94 & Predicted R & 0.9660 \\
\hline & & Adeq Precision & 45.5423 \\
\hline
\end{tabular}

Table.5 Significance of regression coefficients for the removal of $\mathrm{Cd}$

\begin{tabular}{|c|c|c|c|c|c|c|}
\hline Factor & $\begin{array}{c}\text { Coefficient } \\
\text { Estimate }\end{array}$ & df & $\begin{array}{c}\text { Standard } \\
\text { Error }\end{array}$ & $\begin{array}{c}\text { 95\% CI } \\
\text { Low }\end{array}$ & F-value & p-value \\
\hline Intercept & 75.28 & 1 & 1.14 & 72.74 & 85.31 & $<0.0001$ \\
\hline $\begin{array}{c}\text { A- } \\
\text { Concentration }\end{array}$ & 12.94 & 1 & 0.9225 & 10.88 & 111.05 & $<0.0001$ \\
\hline B-Time & 20.43 & 1 & 0.8483 & 18.54 & 170.66 & $<0.0001$ \\
\hline $\mathbf{A B}$ & 0.4587 & 1 & 1.38 & -2.61 & 7.44 & 0.0213 \\
\hline $\mathbf{A}^{\mathbf{2}}$ & -8.59 & 1 & 1.40 & -11.71 & 29.73 & 0.0003 \\
\hline $\mathbf{B}^{\mathbf{2}}$ & -19.98 & 1 & 1.32 & -22.92 & 40.59 & $<0.0001$ \\
\hline
\end{tabular}


Table.6 Chemical compositions of BPB before and after adsorption using EDX analyzer

\begin{tabular}{|c|c|c|}
\hline Element & $\begin{array}{c}\text { Before } \\
\text { adsorption } \\
(\mathbf{W t} \text { \%) }\end{array}$ & $\begin{array}{c}\text { After Cd } \\
\text { adsorption } \\
\text { (Wt \%) }\end{array}$ \\
\hline $\mathbf{C}$ & 68.78 & 70.71 \\
\hline $\mathbf{N}$ & 03.66 & 7.23 \\
\hline $\mathbf{O}$ & 24.61 & 15.84 \\
\hline $\mathbf{Z n}$ & - & - \\
\hline $\mathbf{N a}$ & 0.36 & 0.00 \\
\hline $\mathbf{M g}$ & 0.19 & 0.54 \\
\hline $\mathbf{A l}$ & 0.23 & 0.22 \\
\hline $\mathbf{S i}$ & 0.21 & 0.62 \\
\hline $\mathbf{P}$ & 0.00 & 0.34 \\
\hline $\mathbf{S}$ & 0.00 & 0.00 \\
\hline $\mathbf{P b}$ & 0.00 & 0.33 \\
\hline $\mathbf{C l}$ & 0.14 & 0.23 \\
\hline $\mathbf{C d}$ & 01.12 & 2.21 \\
\hline $\mathbf{K}$ & 00.70 & 1.29 \\
\hline
\end{tabular}

Table.7 FTIR analysis of BPB before adsorption

\begin{tabular}{|c|c|c|c|c|c|}
\hline $\begin{array}{c}\text { Frequency } \\
\left(\mathbf{c m}^{-\mathbf{1}} \mathbf{)}\right.\end{array}$ & Bond & $\begin{array}{c}\text { Functional } \\
\text { Group }\end{array}$ & $\begin{array}{c}\text { Characteristic } \\
\text { Adsorptions } \mathbf{( c m}^{-}\end{array}$ & $\begin{array}{c}\text { Type of } \\
\text { Vibration }\end{array}$ & Intensity \\
\hline $\mathbf{2 9 1 8 . 7 3}$ & C-H & Alkane & $2850-3000$ & stretch & strong \\
\hline $\mathbf{9 9 7 . 9 8 2}$ & =C-H & Alkene & $675-1000$ & bending & strong \\
\hline $\mathbf{7 7 1 . 3 8 7}$ & C-Cl & Alkyl Halide & $600-800$ & stretch & strong \\
\hline
\end{tabular}

Table.8 FTIR analysis of BPB after Cd adsorption

\begin{tabular}{|c|c|c|c|c|c|}
\hline $\begin{array}{l}\text { Frequency } \\
\left(\mathrm{cm}^{-1}\right) \text { for } \\
\text { after Cd } \\
\text { adsorption }\end{array}$ & Bond & $\begin{array}{l}\text { Functional } \\
\text { Group }\end{array}$ & $\begin{array}{c}\text { Characteristic } \\
\text { Adsorptions } \\
\left(\mathrm{cm}^{-1}\right)\end{array}$ & $\begin{array}{c}\text { Type of } \\
\text { Vibration }\end{array}$ & Intensity \\
\hline 2854.13 & $\mathrm{C}-\mathrm{H}$ & Alkane & $2850-3000$ & Stretch & Strong \\
\hline 1015.34 & $\mathrm{C}-\mathrm{O}$ & Ether & $1000-1300$ & Stretch & Strong \\
\hline 770.423 & $\mathrm{C}-\mathrm{Cl}$ & Alkyl Halide & $600-800$ & Stretch & Strong \\
\hline
\end{tabular}


Fig.1 Removal \% of Cd by BPB at different $\mathrm{pH}$

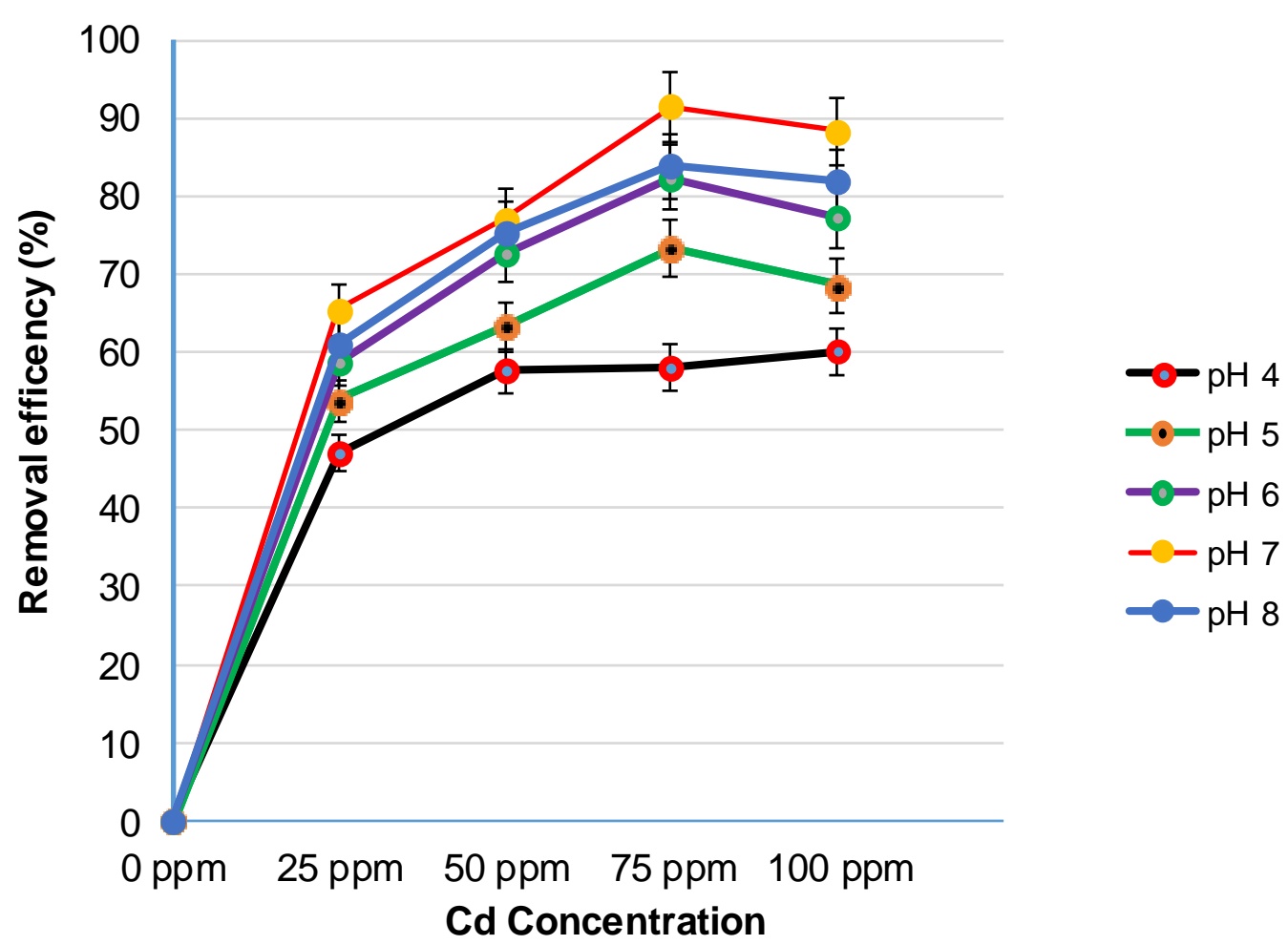

Fig.2 Removal \% of Cd by BPB at different contact time 100

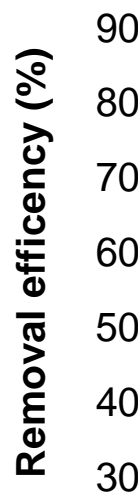

0

0 ppm $\quad 10$ ppm $\quad 25$ ppm $\quad 50$ ppm $\quad 75$ ppm $\quad 100$ ppm Cd Concentration 
Fig.3 Effect of initial metal concentration and $\mathrm{pH}$ on the $\%$ adsorption of $\mathrm{Cd}(\mathrm{BPB})$

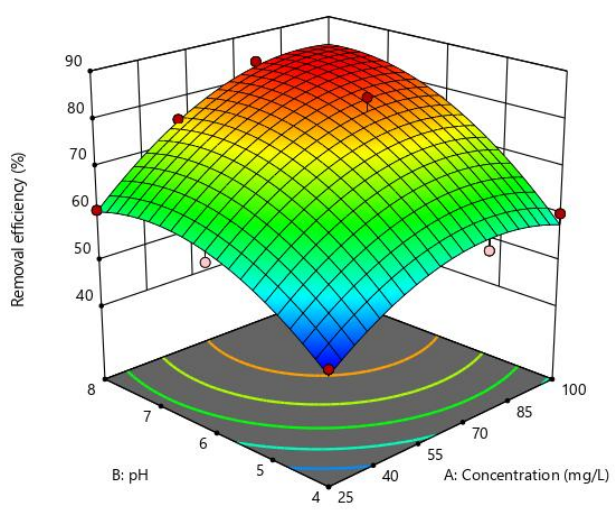

Fig.4 Overlay plot of perturbation of all the variables for BPB

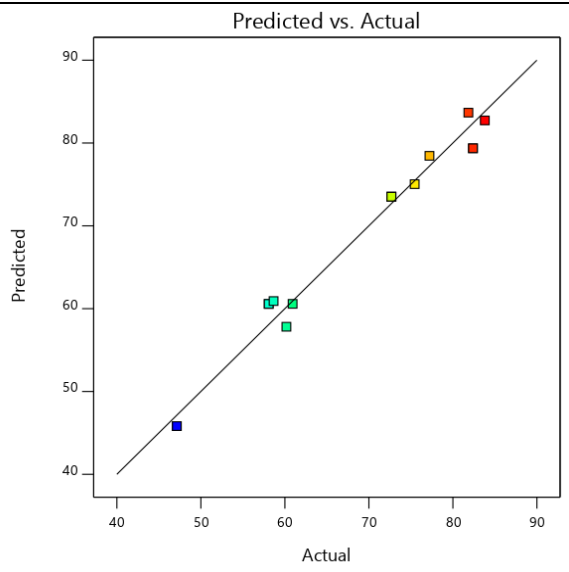

Fig.5 Effect of initial metal concentration and contact time on the on the \% adsorption of $\mathrm{Cd}(\mathrm{BPB})$

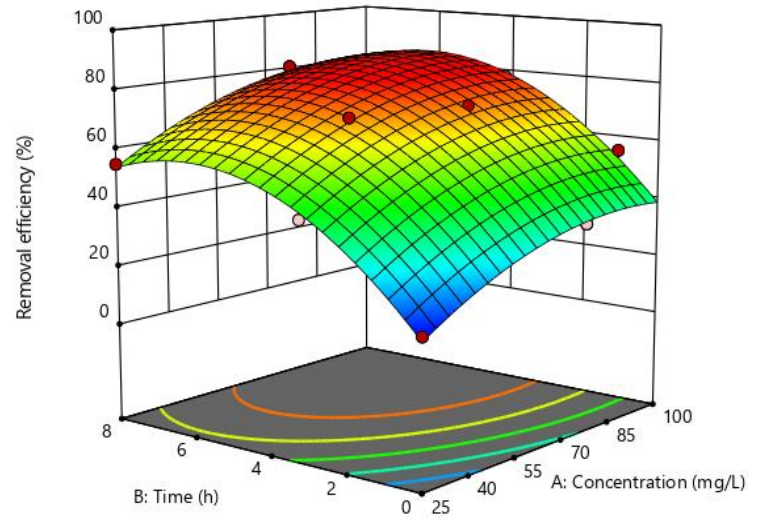

Fig.6 Overlay plot of perturbation of all the variables for BPB

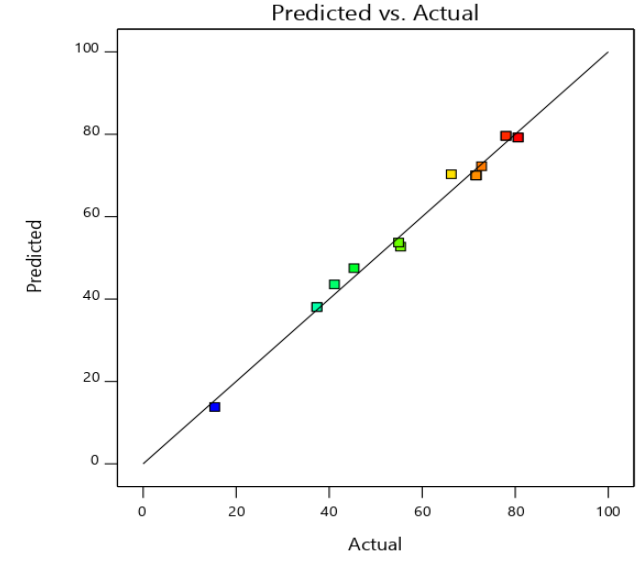

Fig.7 EDX micrograph before Cd adsorption

Fig.8 EDX micrograph after Cd adsorption
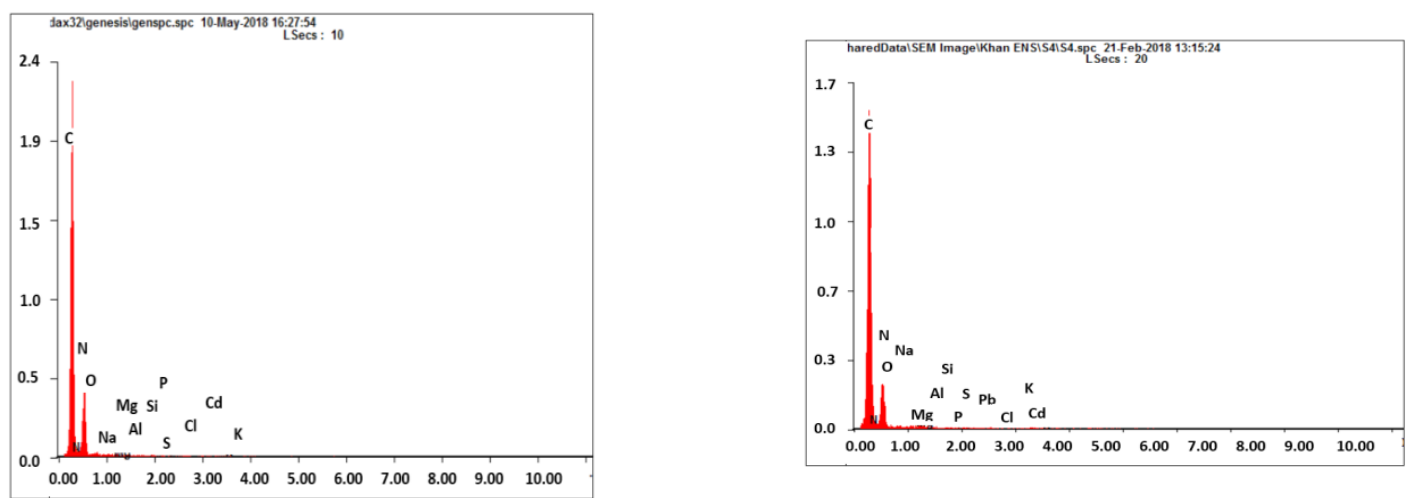
Fig.9a FTIR analysis of BPB before Cadmium adsorption

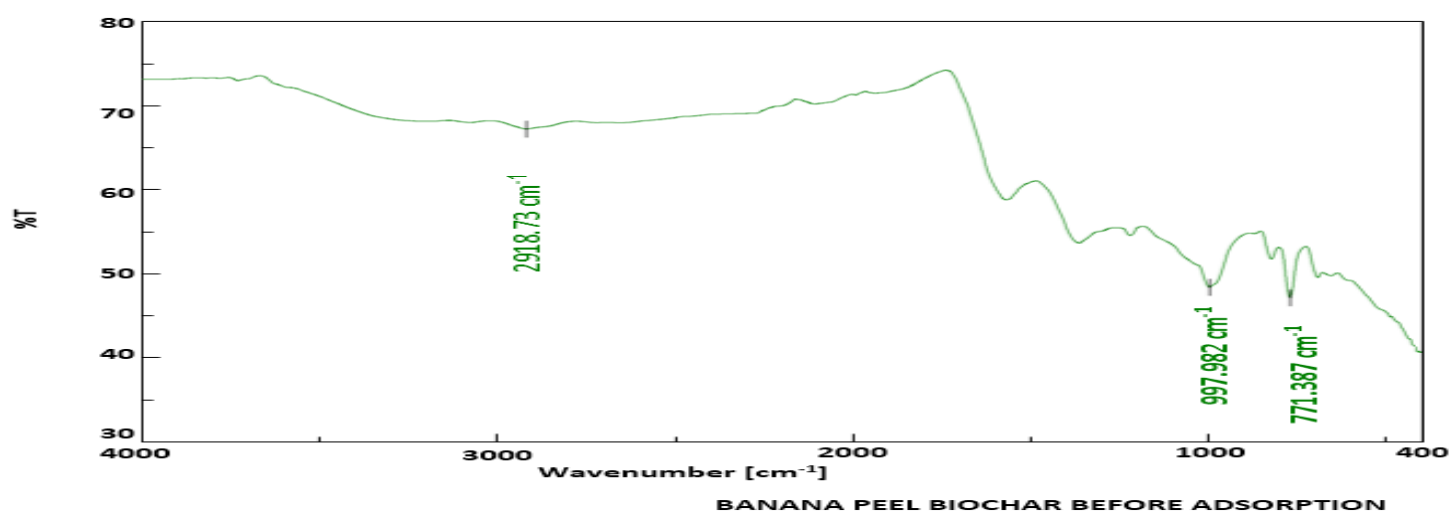

Fig.9b FTIR analysis of BPB after Cadmium adsorption

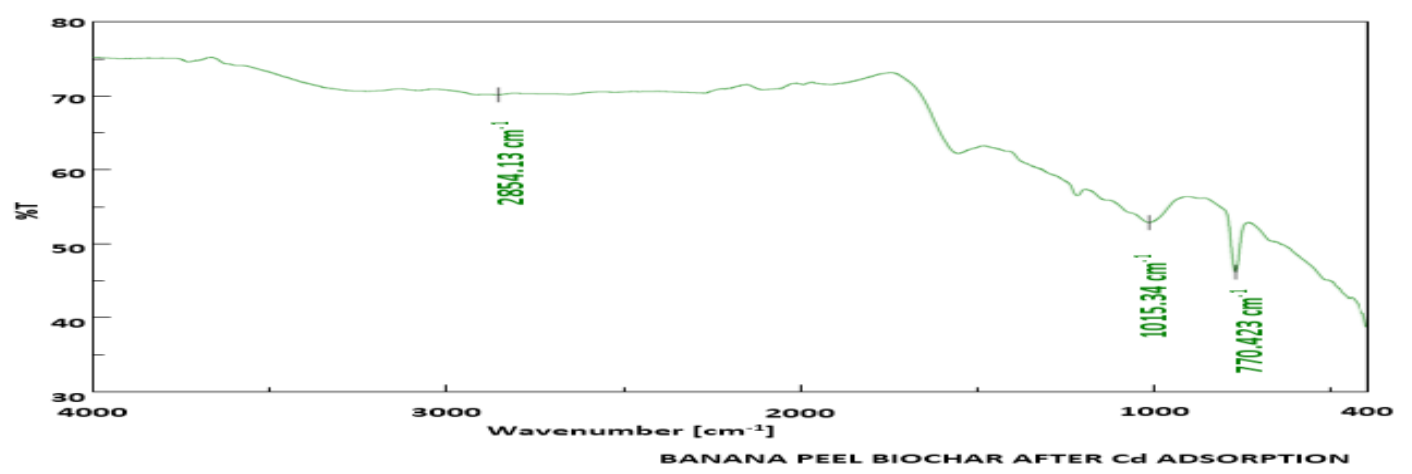

The regression equation coefficient was calculated and data was fitted to a second order polynomial equation. The flat surface on the three-dimensional response indicates an optimum condition for the biosorption (Fig. 3$6)$.

The analysis of variance (ANOVA) for biosorption study of $\mathrm{Cd}(\mathrm{II})$ ions with banana peel adsorbent was used in order to ensure a quadratic model. The test for significance of regression model and the results of ANOVA test for significance of regression model and the results of ANOVA are in Table 3. prob $>F$ less than 0.05indicated model terms are significant (Table 3-5).

The predicted and adjusted $\mathrm{R}^{2}$ values of BPB was $0.9660,0.9854$, which are closer to 1 , indicates the better fitness of model in the experimental data (Fig. 3-4). The regression equation after the analysis of variances (ANOVA) gave the level of cadmium ion removal as a function of the initial cadmium ion concentration, initial solution $\mathrm{pH}$ and contact time. The results of the multiple regression analysis of the data were fitted with a second-order full polynomial equation (Amini, et al., 2008). The empirical relationship between cadmium ion removal $(Y)$ and the independent variables in coded units obtained by the application of RSM is given by

Cd Removal percentage (BPB) $=75.28+12.94 \times \mathrm{A}+20.43 \times \mathrm{B}+0.4587 \times \mathrm{A} \times \mathrm{B}-$ $8.59 \times \mathrm{A}^{2}-19.98 \times \mathrm{B}^{2}(4)$. 
The coefficient estimate represents the expected change in response per unit change in factor value when all remaining factors are held constant. The intercept in an orthogonal design is the overall average response of all the runs. The coefficients are adjustments around that average based on the factor settings.

\section{Characterization of banana peel biochar before and after adsorption of cadmium}

\section{EDX analysis of BPB before and after adsorption}

The elemental composition of BPB before adsorption of $\mathrm{Cd}$ was analyzed through EDX analyzer and the results are given in Table 6 and figure 7. Cadmium to the level of 1.12 on per cent weight basis was observed in BPB. The percentage weight of chemical composition present on the surface of BPB after adsorption of $\mathrm{Cd}$ is given in Table 6 and figure 8. It showed increases in the weight percentage $\mathrm{Cd}$ adsorption. The $\mathrm{Cd}$ content also increased and it was $2.21 \%$ in BPB. This strongly proves that the adsorption of $\mathrm{Cd}$ ions in the selected substrates. There are variations in other elements also and this may be due to the interference in the adsorbed $\mathrm{Cd}$ ions. To our surprise before adsorption of $\mathrm{Cd}$, the $\mathrm{Na}$ was $0.36 \%$ in BPB, but after adsorption there was no sodium at all in BPB. This may be due to $\mathrm{Na}$, the most suitable exchange ion for the removal of $\mathrm{Cd}$ from solution (Maria and Rodney, 1987).

\section{Functional characteristics of biosorbents before and after $\mathrm{Cd}$ adsorption}

The BPB was subjected to FTIR analyses and the results indicated that, the FTIR spectrum peak was observed within $4000-400 \mathrm{~cm}^{-1}$ (Table 7). Alkane, Alkene and Alkyl Halide are the functional groups in BPB before adsorption. The Alkane ring structure $(\mathrm{C}-\mathrm{H}$ stretch) has been recorded at the band, $2918.73 \mathrm{~cm}^{-1}$ in BPB. The band corresponding to Alkene $(=\mathrm{C}-\mathrm{H})$ was detected at 997.982 $\mathrm{cm}^{-1}$ and the band related to Alkyl Halide (C$\mathrm{Cl}$ stretch) was detected at $771.387 \mathrm{~cm}^{-1}$ in BPB (Fig. 9a).

The FTIR spectrum of BPB after $\mathrm{Cd}$ adsorption revealed a large number of peaks within the interval of $4000-400 \mathrm{~cm}^{-1}$, with the complex chemical nature of the bio-material (Table 8 and Fig. 9b). The Alkane ring structure (C-H stretch) has been recorded at the band, $2854.13 \mathrm{~cm}^{-1}$. The band corresponding to Ether $(\mathrm{C}-\mathrm{O})$ was detected at $1015.34 \mathrm{~cm}^{-1}$ and the band related to Alkyl Halide (C-Cl stretch) was detected at 770.423 $\mathrm{cm}^{-1}$ in BPB after $\mathrm{Cd}$ adsorption.

Alkane functional group with $(\mathrm{C}-\mathrm{H})$ band was detected at $2918.73 \mathrm{~cm}^{-1}$ frequency before adsorption but after adsorption of $\mathrm{Cd}$, it was decreased to $2854.13 \mathrm{~cm}^{-1}$ and similar C-H stretching vibration functional group also observed by Hai et al., (2016) before and after adsorption of $\mathrm{Cd}$.

Alkene functional group with $(=\mathrm{C}-\mathrm{H})$ band was reported at $997.982 \mathrm{~cm}^{-1}$ adsorption frequency before adsorption but after adsorption of $\mathrm{Cd}$, the alkene functional group was changed to ether with $(\mathrm{C}=\mathrm{O})$ band at $1015.34 \mathrm{~cm}^{-1}$. There were no changes in Alkyl Halide functional group before adsorption and after adsorption of $\mathrm{Cd}$. In $\mathrm{Cd}$ adsorption, $\mathrm{C}-\mathrm{H}$ group was reduced but $=\mathrm{C}-\mathrm{H}$ increased without change in C-Cl.

The presence of negative charge on the surface of the biochar may be the reason for higher adsorptive capacity of the substrates. Not only the charges, but the functional groups detected in the biochar also increased the potential for adsorbing the metal cations.

In conclusion, detailed study with banana peel 
biochar indicates that the adsorption of cadmium from aqueous solution spiked with different concentration was higher in biochar. The $\mathrm{pH} 7$, solute concentration $75 \mathrm{mg} \mathrm{L}^{-1}$ with a contact time of $6 \mathrm{~h}$ was found to be optimum for the maximum removal of $\mathrm{Cd}$. Hence ecofriendly wastes like banana peel can be used for heavy metal removal from the wastewater.

\section{Acknowledgment}

The author thank M/S SMS Banana Chips industry, Priya Nagar, Telungupalayampirivu, Perur main rood, Coimbatore - 641039 for the supply of peels whenever needed. The authors also wish to place their thanks to the Department of Bioenergy for the help rendered in biochar preparation during the study.

\section{References}

Anhwange, B., and Joseph, T. U. (2009). Chemical Composition of Musa sepientum (Banana) Peels. Elect. $J$. Envi., Agri. and Food Chemi, 8(6), 437442.

Anwar, J., Shafique, U., Waheed-uz-Zaman, Salman, M., Dar, A., and Anwar, S. (2010). Removal of $\mathrm{Pb}$ (II) and $\mathrm{Cd}(\mathrm{II})$ from water by adsorption on peels of banana. Biores. Technol, 101, 17521755.

Ashraf, M. A., Mahmood, K., Wajid, A., Maah, M. J., and Yusoff, I. (2011). Study of low cost biosorbent for biosorption of heavy metals. International Conference on Food Engineering and Biotechnology, 9, 6068.

ATSDR. (2007). Toxicological profile for lead-update. Agency for Toxic Substance and Disease Registry. Atlanta: U.S. Department of Health and Human Services, Public Health Service.
Available

online:

http://www.atsdr.cdc.gov/toxprofiles/tp1

3.pdf (582 pages). (Accessed on $03 / 20 / 2018$ )

Cheng, Z. J., R. W. H. (2003). No TitleEffects of extrusion and expelling processing, and microbial phytase supplementation on apparent digestibility coefficients of nutrients in full-fat soybeans for rainbow trout (Oncorhynchus mykiss). Aquaculture, 218(1-4), 501-514.

Ghosh A, Dastidar, M, and Sreekrishnan, T. Recent advances in bioremediation of heavy metals and metal complex dyes. Journal of Environmental Engineering, 2015; 142(9), C4015003.

Gomez-Eyles, J., Beesley, L., MorenoJimenez, E., Ghosh, U., and Sizmur, T. (2013). The potential of biochar amendments to remediate contaminated soils. In: N. Ladygina and F. Rineau, editors, Biochar and Soil Biota. CRC Press, Boca Raton, FL. (Accessd on 20/05/2018). Avalable onlne: https://www.researchgate.net/post/What_ causes_high_CEC_in_biochars

Gupta, P. K. (2007). Methods in Environmental Analysis Water, Soil and Air (2nd ed.). Agrobios (India), Jodhpur.

Hai NT, Sheng-Jie Y, and Huan-Ping C. Effect of pyrolysis temperatures and times on the adsorption of cadmium onto orange peel derived biochar, International solid waste association, 2016; 34(2), 129-138.

Jackson, M. L. (1973). Soil chemical Analysis. Prentice Hall of India (Pvt.) Ltd., New Delhi.

Jamil, R. M., Memon, S. Q., Bhanger, M. I., Memon, G. Z., El-Turki, A., and Allen, G. C. (2008). Characterization of banana peel by scanning electron microscopy and FT-IR spectroscopy and its use for cadmium removal. Collo. and Surfa. B: Biointerfaces, 66, 260-265.

Kilic, M., Kirbiyik, C., Cepeliogullar, O., and 
Putun, A. E. (2013). Adsorption of heavy metal ions from aqueous solutions by biochar, a by-product of pyrolysis. Applied Surf. Sci., 283, 856-862.

Kokila, T., Ramesh, P.S., and Geetha, D. (2015) Biosynthesis of silver nanoparticles from Cavendish

banana peel extract and its antibacterial and free radical scavenging assay: a novel biological approach, Applied Nanoscience, 5(8): 911-920.

Liu, Z., and Zhang, F.. (2010). Characterization and application of chars produced from pinewood pyrolysis and hydrothermal treatment. Fuel, 89(2), 510-514.

Maria, L., and Rodney, P.T. (1987). Exchange of cadmium into the sodium and ammonium forms of the natural zeolites clinoptilolite, mordenite, and ferrierite, J. Chem. Soc., Dalton Trans.,0, 1911-1916.

Mohapatra, D., Sabyasachi, M., and Namuata, S. (2010). Banana and its by-product utilization: an overview. J. Scientific and Indus. Res., 69, 323-329.

Natalia, A. F., Liovando, M. C., Leonidas, C. A. M., Evair, A. S., and Jairo, T. (2017). Characterization of biochars from different sources and evaluation of release of nutrients and contaminants. Artigo Científico, 48(3), 395-403.

Priyanka, K. (2017). A low cost material, Banana peel for the removal of Lead (II) from aqueous solutios. Int. Res. J. Eng. and Technol., 4(6), 1404.

Sadasivam, S., and Manickam, A. (2009). Biochemical Methods (3rd ed.). New age international (pvt) Ltd., New Delhi,
India.

Shafaghat, A., Salimi, F., Valiei, M., Salehzadeh, J., and Shafaghat, $M$. (2012). Removal of heavy metals $\left(\mathrm{Pb}^{2+}\right.$, $\mathrm{Cu}^{2+}$, and $\mathrm{Cr}^{3+}$ ) from aqueous solutions using five plants materials. Afr. $J$. Biotechnol., 11, 852-855.

Srivastava, V., Indra, D. M., and Indra, M. M. (2016). Modelling Individual and Competitive Adsorption of Cadmium(II) and Zinc(II) Metal Ions from Aqueous Solution onto Bagasse Fly Ash. $J$. Separa. Sci. and Technol., 41(12), 26852710.

Tandon, H. L. S. (2013). Methods of Analysis of Soils, Plants, Waters, Fertilizers and Organic Manures. Fertilizer Development and Consultation Organisation, New Delhi. India. Pp. 204. Trakal, L., Bingol, D., Pohorely, M., Hruska, M., and Komarek, M. (2014). Geochemical and spectroscopic investigation of $\mathrm{Cd}$ and $\mathrm{Pb}$ sorption mechanisms on contrasting biochar: Engineering implications. Biores. Technol., 171, 442-451.

Ucar, S., Erdem, M., Tay, T., and Karagoz, S. (2014). Removal of Lead (II) and Nickel (II) ions form aqueous solution using activated carbon prepared from rapeseed oil cake by $\mathrm{Na}_{2} \mathrm{CO}_{3}$ activation. Clean Technol. Envi. Policy, 17(3), 747-756.

Zhou, M., Liu, Y., Zeng, G., Li, X., Xu, W., and Fan, T. (2007). Kinetic and equilibrium studies of $\mathrm{Cr}$ (VI) biosorption by dead Bacillus licheniformis biomass. World J. Microbiol. Biotechnol, 23, 43-48.

\section{How to cite this article:}

Dhevagi, P., S. Priyatharshini and Ramya, A. 2019. Response Surface Methodology as a Tool for Optimization of Metal Adsorption by Banana Peel Biochar. Int.J.Curr.Microbiol.App.Sci. 8(12): 996-1009. doi: https://doi.org/10.20546/ijcmas.2019.812.128 